\title{
A Review of Researches on Job Search Clarity
}

\author{
Wei Wang, Liangtie Dai \\ School of Management, Jinan University, Guangzhou, China \\ Email:277545921@qq.com
}

How to cite this paper: Wang, W., \& Dai, L. T. (2017). A Review of Researches on Job Search Clarity. Psychology, 8, 955-962. https://doi.org/10.4236/psych.2017.87062

Received: March 16, 2017

Accepted: May 13, 2017

Published: May 16, 2017

Copyright ( $) 2017$ by authors and Scientific Research Publishing Inc. This work is licensed under the Creative Commons Attribution International License (CC BY 4.0).

http://creativecommons.org/licenses/by/4.0/

\begin{abstract}
Job search clarity refers to a job seeker's clarity about his job objective or about his desired job in terms of content or form. Job search clarity has an important influence on career development of both contemporary college students and the employed. Particularly, along with intensifying of supply and demand contradictions on the current labor market, and deepening of personnel reform, an increasing number of college students and the employed are obsessed with their career problems. This makes research and guidance of job search clarity an imperativeness. By reviewing previous literatures and combining the development status in China, this research further summarizes the concept, measurement methods, influencing factors and results of job search clarity, and provides some measures to improve college students' job search clarity. Besides, the author looks into prospects of the research issue, hoping that research into job search clarity can go deeper and be further expanded.
\end{abstract}

\section{Keywords}

Job Search Clarity, Job-Seeking College Students, Career Development

\section{Introduction}

China is now at a critical development period of socialist market-oriented economy with Chinese characteristics. However, in recent years, economic development has been slowed down, leading to gradual evolution of employment systems of enterprises and institutions. In response to intensifying supply and demand contradictions on the labor market, China's institutions of higher learning have expanded their enrollment. Consequently, there has been an upsurge in the number of graduates. Currently, higher education is transitioning from an "elite education" to the "public education". All these factors have worsened the employment status of university students, and the problem has drawn increasing attention. To most graduates, the transition from the "ivory tower" at school to the workplace is not an easy process. Many of them feel confused 
about their career planning, career selection and career objectives, which are collectively known as "job search clarity".

Wanberg et al. (2002) proposed the concept of "job search clarity", thinking that it refers to the job seeker's clarity about his job objective or about his desired job in terms of content or form. Western scholars have already built a complete research framework for job search clarity. However, in China, research into job search clarity is still insufficient. In some empirical research, job search clarity is studied as a variable of functioning conditions. The research content has not yet formed a systematic structure. As a part of management science and psychology, research into job search clarity has practical significance. Concerning the research gap, this paper summarizes the research status at home and abroad, systematically reviews relevant literatures of job search clarity, expounds on the concept, measurement methods, influencing factors and results of job search clarity, and looks into the future of the research issue. Finally, measures to improve job search clarity of college students are put forward at an attempt to increase the academic and practical research significance of this research into job search clarity.

\section{Concept of Job Search Clarity}

Based on research into unemployment groups, Wanberg et al. (2002) raised the idea of "job search clarity" the first time, and defined it as the job seeker's clarity about his job objective or about his desired job in terms of content or form. The definition was put forth from the perspective of objective setting. Objective is something one wants to accomplish. It can influence a person's behaviors through four mechanisms, including drawing individual attention, maintaining a period of efforts, increasing sustainability, and encouraging individuals to come up with strategies to realize the objective. Meanwhile, to clarify an objective hard to achieve can bring better performance, because the objective can guide the behavior direction of individuals and increase the degree of their concentration (Zhong, 2013). Based on the definition of Wanberg, Cote et al. (2006) thought that job search clarity should not only refer to a job seeker's clarity about his job objective and job search direction, but also include the job seeker's clarity about when and how to find a job. Guo et al. (2005) pointed out that job search clarity should include an individual's cognition of his job objective, approach to realizing his job objective, potential obstacles and countermeasures, and potential changes of career development.

Based on the above research findings, this paper defines job search clarity as a clear understanding of the job-seeker about his job objective, approach to realizing his job objective, methods and obstacles in selecting job, and countermeasures to cope with these obstacles.

\section{Methods to Measure Job Search Clarity}

Research into methods to measure job search clarity has not yet started long. In 2006, Cote et al. spearheaded efforts to compile a one-dimensional job search 
clarity questionnaire survey, which is also a 10 -item scale. Among them, six questions are positive points. For example, "if I am interested in a job, I can persuade the employer to recruit me". The remaining four are negative points. For example, "On the whole, my individual conditions cannot impress the employer deeply". The five-point Likert scale is adopted, which ranges from " $1=$ Strongly disagree" to " $5=$ Strongly agree". The higher the points are, the higher the job search clarity is.

Guo et al. (2005) thought that job search clarity should include the individual's cognition of his job objective, approach to realizing his job objective, and potential obstacles and countermeasures, and potential changes of career development. However, they failed to come up with a scale to measure the four dimensions.

Liao (2007) studied job search behaviors of students in Taiwan business schools, and refined 10 questions involved in the questionnaire compiled by Cote et al. into five, "I haven't decided my career", "I have planned my career", "I know what kind of job that I want", "I know how to fulfill my career goal", "I often change my career goal".

\section{Influencing Factors of Job Search Clarity}

Based on the existing literature, this paper mainly summarizes factors influencing job search clarity from three aspects, namely individual factors, environmental factors and self-efficacy.

\subsection{Individual Factors}

Individual factors and personality factors can influence job search clarity of college students. Individuals which are active in actions and thinking, and strong in achievement motivation and sense of crisis will actively seek job search information, and try different opportunities to gradually increase their job search clarity. On the contrary, individuals with a passive attitude towards job search or without a sense of crisis or unclear about their job objective might easily follow the trend, lose many golden opportunities and take longer time to form job search clarity (Shen, 2015).

The social support system of individuals can also influence college students' job search clarity. A strong social support system, including support from the family, friends and other social resources, can allow college students to have access to more social resources and interpersonal resources, and develop job search clarity easily (Kanfer et al., 2001).

Besides, individual academic degree, knowledge, skills and abilities can all influence job search clarity of college students. The higher the academic degree an individual has, the more targeted his research field is, and the clearer he is about his job objective. For example, though students graduating from polytechnic schools do not have a high academic degree like undergraduates, they usually have acquired a skill to make a living, so their job search clarity is usually higher than that of undergraduates. Therefore, it is necessary for undergraduates to find 
a skill they are interested while studying at school, which can be very helpful to their future career development (Guo, 2005).

\subsection{Environmental Factors}

Environmental factors influencing college students' job search clarity are mainly reflected as economic environmental and regional differences: Currently, China's economic development has been slowed down. Increasing saturation on the job market and deepening of personnel reform have led to gradual evolution of employment systems in enterprises and institutions. The employment status of graduates is becoming increasingly severe. College students often feel helpless or even at a loss on the job market, which is beneficial for them to form a high job search clarity. Besides, economic development in China is disproportional. East China has a higher economic development level. Compared with graduates in Central and Western China, graduates can have access to more resources and seek more job opportunities in East China, which can contribute to formation a higher job search clarity (Wang, 2016).

\subsection{Self-Efficacy}

Self-efficacy is a concept first put forward by Bandura (1977), an American psychology. It is at the core of social recognition theories, referring to an individual's belief in his own ability to accomplish certain task and reach certain goal Bandura (1977). Bandura (1977) thought that a low self-efficacy of certain behavior of behavioral field might push the individual to avoid certain behavior or result in poor performance of the individual; while a high self-efficacy can help get the individual closer to his goal. College students' job search clarity is influenced by their sense of self-efficacy. Individuals confident in their ability to make correct job decisions will more easily form a higher job search clarity; while those with a low self-efficacy of their job decisions will have no confidence to make a choice, thus having a low job search clarity (Ye, 2017).

\section{Influencing Results of Job Search Clarity}

Job search clarity can influence every aspect of individuals. The most direct influence is reflected on their job search behaviors and career decision-making. Gradually, job search clarity will also exert an influence on occupational status.

\subsection{Job Search Behavior}

Job search behavior refers to the process in which the job-seeker make full use of their own and external resources to achieve his job objective. As to job behavior of college students discussed in this paper, it consists of job search intensity and job search information search strategy. Job search intensity means the frequency of the job-seeker involving in different job search activities. It can be the frequency of an individual searching employment information on the Internet or from newspapers, or the frequency of an individual participating in interviews of employers. Generally speaking, job intensity can be further divided into job 
search preparation and substantial job search behavior. Job search preparation, as the name implies, is a process in which the job-seeker searches job information from different information channels, while substantial job search behavior refers to the process in which the job-seeker screens out his job objective and officially searches his job, such as sending CVs and participating in interviews. Research shows that job search clarity can influence an individual's job search behavior. The higher the job search clarity is, the more frequent the job search behavior of an individual is (Wang, 2016).

\subsection{Career Decision-Making}

Career decision-making means that an individual pins down his job objective after evaluating different conditions and participating in different activities, and formulates an optimal action plan for himself to realize the job objective. Wang (2010), a Chinese scholar, studied the influence of job search clarity on career decision-making, finding out that job search clarity can influence the level of job decision-making. When job search clarity of an individual is high, he can effectively overcome different difficulties during the career decision-making process.

\subsection{Occupational Status}

The so-called Occupational status refers to the overall situation of economic income, personal values, social status and social prestige and other aspects, in one's career. Chinese scholars Mo and Wang (2011) through their study found that. Job search clarity will affect the individual's ultimate Occupational status. Individuals with higher levels of job search clarity can often find high-paying jobs which can realize their personal ideals and aspirations, with higher social status and social prestige; while Individuals with lower levels of job search clarity always get Lower Occupational status.

\section{Countermeasures}

Intervention research targeted at improving college students' job search clarity is still limited. Concerning the current research status, intervention of job search clarity mainly includes family intervention, school intervention, individual intervention and social intervention. In the future, neurosciences might also intervene in job search clarity, but this relies on future development of neurosciences. In the following part, the author focuses on countermeasures adopted by family, school, individual and society to improve college students' job search clarity.

\subsection{Family}

Family is considered a person's harbor of refuge. The job search process is often the most confusing period to a college student. At such moments, parents should be the most powerful backing for their children. Apart from emotional support, parents should also properly provide economic support. However, it is not suggested that parents should intervene too much in college students' career explora- 
tion. In this way, college students can focus on their desired job after finding one.

\subsection{School}

Institutions of higher learning should not only infuse students with theoretical knowledge, but also develop students' professional skills based on development requirements of the era and society. Otherwise, what students have acquired from institutions of higher learning might deviate from demands of their prospective employers. Meanwhile, in order to facilitate college students' career exploration, schools can seek cooperation with relevant employers to create more internship or job opportunities for students. Besides, when the graduation season comes, schools should actively organize job fairs and invite some employers to hold career talks in their campuses. Or some professionals can be invited to teach students job search knowledge and skills, with which college students can more easily form their job search clarity (Wang, 2013).

\subsection{Individuals}

At school, college students can take an active part in students' associations so as to hone their organizing, planning, and teamwork ability, and learn how to get along with roommates, classmates and teachers through different activities. Besides, internships are important to college students, which give students opportunities to turn their knowledge into skills and lay a solid foundation for their future job search. Last but not least, college students should develop an objective cognition of their personality and comprehensive qualities. If possible, college students can take vocational orientation tests to evaluate which position is the most suitable for them (Wang, 2013).

\subsection{National Policies}

The employment status of the whole society is subject to the national economic development level. Thus, China should vigorously develop its economy to create more job opportunities. Meanwhile, college students should be encouraged to start up their own business under the experience and fund support. National policies should create conveniences for college students to start up their own business. In this way, college students' entrepreneurship enthusiasm will be greatly stimulated, thus contributing to improvement of China's national comprehensive strength.

\section{Research Prospects}

Job search clarity emerges as a new research field. The author thinks that efforts should be intensified in the following aspect to deepen the research of job search clarity:

\subsection{Combination of Horizontal Research with Longitudinal Research}

From the perspective of research methods, longitudinal research into job search clarity is insufficient. This is probably because that job search clarity is still a new 
research field. Most scholars focus on horizontal research. Since one's job lasts throughout one's life, the research time period can also be extended into the future, such as five years or ten years after graduation. Then, the longitudinal research results can be compared with the horizontal research results to find out differences and development rules.

\subsection{Promotion of Research Results}

Currently, scholars still focus on college students while studying job search clarity. In fact, job search behaviors are not exclusive to college students but widespread in many other social groups. Thus, in the future, scholars can extend their research to other social groups, such as workers. Of course, factors influencing job search clarity of college students and workers are not completely the same, but there must be some similarities. Research into job search clarity of college students can also provide references for research into other social groups.

\subsection{Influence of Cultural Factors}

Factors influencing job search clarity of college students from different cultural backgrounds and the countermeasures are undoubtedly different. Thus, Western research findings can just serve as references instead of being adopted as experiences directly. At present, there is almost no theoretical and empirical research into job search clarity in China. Along with expanded enrolment in institutions of higher learning, the number of college students keeps growing. However, impacted by the world economic recession, many countries are struggling to make a recovery. Under the condition, employment of all ranks of society has received increasing attention from the national government. The job search behaviors of different social groups in China are calling for in-depth discussion and exploration by the academic circles. In the future, it is necessary to study job search behaviors against the background of China's cultural background. Only in this way can problems and challenges facing Chinese social groups during their job search be effectively resolved.

\section{Conclusion}

By reviewing previous research findings, this paper systematically explores the concept, measurement methods, influencing factors and results of job search clarity, proposes countermeasures to improve college students' job search clarity, and points out possible research directions in the future. To sum up, this research has enriched the job search clarity studies in China, and it has both academic and practical significance.

\section{References}

Bandura, A. (1977). Selfeffieaey: Toward a Unifying Theory of Behavior Change. Psychological Review, 84, 191-215. https://doi.org/10.1037/0033-295X.84.2.191

Cote, S., Saks, A. M., \& Zikie, J. (2006). Trait Affect and Job Search Outcomes. Journal of Vocational Behavior, 68, 233-252. https://doi.org/10.1016/j.jvb.2005.08.001 
Guo, Y., Chen, J. Q., \& Wang, L. (2005). Job Search Clarity: Concept, Investigation, Analysis and Application. Human Resources Development of China, 2, 22-25.

Kanfer, R., Wanberg, C. R., \& Kantrow, T. M. (2001). Job Search and Employment: A Personality-Motivational Analysis and Meta-Analytic Review. Journal of Applied Psychology, 86, 837-855. https://doi.org/10.1037/0021-9010.86.5.837

Liao, W. H. (2007). A Study on Student's Job Hunting Behavior in Colleges of Science and Business in Taiwan. Master's Thesis. Taiwan: National Central University.

Mo, Sh. Sh., \& Wang, Ch. (2011). An Empirical Study on the Factors Affecting the Initial Occupational Status of College Students-Based on the Research of Some Universities in Hebei Province. Business Culture, 7, 93-94.

Shen, X. P., \& Hu, T. (2015). Relationship between Proactive Personality and Job Search Clarity of Undergraduate Students: Calling as a Mediator and Moderator. Chinese Journal of Clinical Psychology, 1, 166-170.

Wanberg, R. C., Hough, L. M., \& Song, Z. (2002). Predictive Validity of a Multidisciplinary Model of Reemployment Success. Journal of Applied Psychology, 87, 1100-1120.

Wang, Ch. (2010). Relationship among Decision-Making Style, Self-Management Strategies, Job Searching Clarity and Career Decision-Making Difficulties of College Students. Master's Thesis, Jinan: Shandong Normal University.

Wang, J. (2016). A Study on Job Searching Clarity, Job Searching Behaviors and Job Searching Results of University Students. Master's Thesis, Tianjin: Tianjin Normal University.

Wang, J. Y. (2013). A Study of the Employment Intelligibility of College Students-A Case Study of the Students of Science and Engineering in a Key University of Fuzhou. Journal of Shangrao Normal University, 5, 114-118.

Ye, B. J., Zheng Q., Dong, Sh. H. et al. (2017). The Effect of Calling on Employability of College Students: The Mediating Role of Job Searching Clarity and Job Searching Self-Efficacy. Psychological Development and Education, 1, 37-44.

Zhong, L. L., Wang, Ch., Si, J. W. et al. (2013). Relationships among Self-Management Strategies, Clarity of Job Searching and Career Decision-Making Difficulties in College Students with Rational Decision-Making Style. Psychological Research, 3, 88-94.

\section{Submit or recommend next manuscript to SCIRP and we will provide best service for you:}

Accepting pre-submission inquiries through Email, Facebook, LinkedIn, Twitter, etc. A wide selection of journals (inclusive of 9 subjects, more than 200 journals)

Providing 24-hour high-quality service

User-friendly online submission system

Fair and swift peer-review system

Efficient typesetting and proofreading procedure

Display of the result of downloads and visits, as well as the number of cited articles

Maximum dissemination of your research work

Submit your manuscript at: http://papersubmission.scirp.org/

Or contact psych@scirp.org 